\title{
МОТИВАЦІЯ НАВЧАННЯ СТУДЕНТІВ В УМОВАХ ДИСТАНЦІЙНОГО НАВЧАННЯ
}

\author{
MOTIVATION OF STUDENTS 'LEARNING \\ IN THE CONDITIONS OF DISTANCE LEARNING
}

УДК 159.9.072.432

DOI https://doi.org/10.32843/2663-

5208.2020.17.10

\section{Головська І.Г.}

\section{к.психол.н.}

доцент кафедри теорії та методики практичної психології

Південноукраїнський національний педагогічний університет

імені К.Д. Ушинського

\section{Лазоренко Т.М.}

к.психол.н., доцент кафедри теорії та методики практичної психології

Південноукраїнський національний педагогічний університет

імені К.Д. Ушинського

\section{Чернєва T.М.}

бакалавр, студентка I курсу

магістратури зі спеціальності

«Психологія»

Південноукраїнський національний педагогічний університет

імені К.Д. Ушинського
Стаття присвячена дослідженню мотиваціі навчання студентів в умовах дистанційного навчання, адже на цей час це одна із найбільш актуальних $і$ болючих тем для всіх вищих навчальних закладів. Суспільство вимагає від студентів високих результатів, але для того щоб ВНЗ виховав зі своїх студентів професіоналів, вони самі повинні жадати стати справжніми професіоналами свого діла. А ми не можемо уявити справжнього квалісрікованого фрахівия, який не любить і не розвивається у своїй професії, своєму ділі. I тут одним із найголовніших аспектів стає мотивація.

Сучасні вчені вже давно зачікавлені мотивацією студентів, і це є дуже важливою темою для вивчення, бо від цього залежить професійне майбутнє наших дітей. Вивчення мотивації студентів завжди було дуже важливою темою, але зараз це набуло ще більшого значення. Адже дистанційне навчання внесло у че поняття свої корективи і змусило подивитися на мотивацію студентів до навчання зовсім під іншим кутом. Як зацікавити, вмотивувати студентів навчатися, коли прямого контакту у нас 3 ними немає? Як зберегти любов до науки та знань, коли вони отримують всю інфрормацію лише з екрану моніторів?

у статmі ми висловлюємо наш погляд на зазначену проблему, а також пропонуємо проаналізувати наукову літературу, дослідити поняття «мотивації» та особливост ї̈ проявів й розвитку у студентів. Крім того, в статmі представлене дослідження мотивації студентів в умовах дистаниійного навчання. Дослідження проводилося серед 100 студентів 3 та 4 курсу спеціальності «Психологія» ПНПУ ім. Ушинського. Слід зазначити, що вся діагностика проводилася в умовах дистаниійного навчання, що робить результати дослідження більш істинними. Для діагностики ми використали такі методики: «Методика для діагностики навчальної мотивації студентів (А.А. Реана і В.А. Якуніна, модифрікація Н.Ц. Бадмаєвой)», «Мотивація навчання у вузі» (Т.H. Ільїноі), «Мотиви вибору професії» (Р.В. Овчарова) та розроблена нами анкета.

Ключові слова: мотивація, студенти, ВНЗ, дистанційне навчання.
The article is devoted to the study of student motivation in distance learning, because at the moment it is one of the most relevant and painful topics for all higher education institutions. Society demands high results from students, but in order for a university to educate professionals from its students, they themselves must be willing to become true professionals in their field. And we cannot imagine a real qualified specialist who does not like and does not develop in his profession, his business. And here one of the most important aspects is motivation.

Modern scientists have long been interested in student motivation and this is a very important topic to study, because it depends on the professional future of our children. Studying student motivation has always been a very important topic, but now it has become even more important. After all, distance learning has made its adjustments to this concept and forced to look at the motivation of students to learn from a completely different angle. How to interest, motivate students to study when we do not have direct contact with them? How to keep the love of science and knowledge when they receive all the information only from the monitor screen?

In the article we express our point of view on this problem, and also offer to analyze the scientific literature, to explore the concept of "motivation" and the peculiarities of its manifestations and development in students. In addition, the article presents a study of student motivation in distance learning. The study was conducted among 100 3rd and 4th year students majoring in "Psychology" PNPU named after Ushinsky. It should be noted that all diagnostics were performed in the conditions of distance learning, which makes the results of the study more true. For diagnosis, we used the following methods: "Methods for diagnosing the learning motivation of students (A.A. Rean and V.A. Yakunin, modification of NTS Badmaeva)", "Motivation of higher education" (T.N. Ilyina), "Motives for choosing a profession" (R.V. Ovcharova) and the questionnaire developed by us.

Key words: motivation, students, universities, distance learning.
Постановка проблеми. Мотивація студентів до навчання зараз $є$ однією з найактуальніших тем. Сучасність ставить перед студентами високі вимоги, але для того щоб ВНЗ виховав зі своїх студентів професіоналів, вони самі повинні жадати стати справжніми професіоналами свого діла. А тут одним із найголовніших аспектів стає мотивація. Вивчення 
мотивації студентів завжди було дуже важливою темою, але зараз це набуло ще більшого значення. Але чому? Тому що в умовах дистанційного навчання, відсутності потреби ходити до навчального закладу, багато хто з них сприймають це як позачергові канікули. Це пояснюється тим, що студенти постійно сидять вдома, поруч зі своїми батьками та родичами, і в цих умовах немає ніякої мотивації від оточення. А з іншого боку, активне спілкування з одногрупниками та викладачем, можливість самостійно вирішувати терміни та час навчання зменшують завантаженість студентів, і тим самим підвищують мотивацію до навчання. Так що ж із цього $є$ істинним? Саме цю проблему ми хочемо розглянути у цій роботі [6].

Також важливо сказати, що навчання у вищому навчальному закладі $€$ сходинкою до майбутньої професії, до дорослого життя. Тому навчання і придбання знань $€$ дуже важливим аспектом у цей період. А без мотивації до навчання ніяких висот не досягти, а в умовах дистанційного навчання тим паче.

Вивченням мотивації студентів у навчанні під час дистанційного навчання займалися багато психологів, зокрема: Л.І. Божович, Г.С. Костюк, М. В. Матюхіна, Д. Макклелланд, Д. Аткінсон, Г. Хекхаузен, К. Роджерс, Р. Мей, А.Н. Леонтьєв, Є. П. Ільїн, В. Г. Леонтьєв, А. К. Маркова, А. О. Реан та інші.

Актуальність обраної теми зумовлена недостатньою розробленістю цього питання в сучасній психології, а також необхідністю розв'язання проблеми мотивації студентів під час дистанційного навчання, оскільки навчання у ВНЗ $є$ одним із найважливіших аспектів щодо майбутнього людини, саме в цей період вона визначає своє майбутнє у професії.

Постановка завдання. Мета статті полягає у дослідженні мотивації навчання студентів в умовах дистанційного навчання.

Згідно з поставленою метою були визначені такі завдання:

1. Проаналізувати теоретичні аспекти поняття мотивації до навчання як соціально-психологічного явища;

2. Визначити чинники, що впливають на прояв мотивації студентів до навчання.

3. Виконати теоретичне дослідження мотивації навчання студентів в умовах дистанційного навчання на основі вивченої літератури;

4. Експериментально вивчити рівень мотивації в умовах дистанційного навчання у досліджуваній групі, здійснивши кількісний і якісний аналіз отриманих даних;

5. Проаналізувати теоретичний матеріал з корекції мотивів;

6. Розробити рекомендації для посилення мотивації до навчання в умовах карантину.
Методи дослідження: теоретичні: аналіз літератури; емпіричні: психодіагностичні методики: «Методика для діагностики навчальної мотивації студентів» (А.А. Реана і В.А. Якуніна, модифікація Н.Ц. Бадмаєвой), «Мотивація навчання у вузі» (Т.Н. Ільїної), «Мотиви вибору професії» (Р.В. Овчарова) та розроблена нами анкета; математичні: кількісний та якісний аналіз результатів дослідження; корекційна робота.

Виклад основного матеріалу дослідження. Мотивація - це готовність людини докладати максимум зусиль задля досягнення своєї мети, якщо ця мета задовольняє якусь певну потребу цієї людини [1].

Проблемою мотивації займалася велика кількість вітчизняних та закордонних психологів.

Вивчення проблеми мотивації людини пояснюється тим, що люди в усі часи не могли зрозуміти, що саме керує людиною і спонукає ії̈ на ті чи інші вчинки, заради чого або заради кого вона діє, який мотив керує нею.

Дуже важливим питанням для суспільства в умовах сучасності стає проблема того, як підвищити ефективність навчання студентів загалом. Одним із найбільш цікавих питань $€$ та залишається питання про мотивацію навчальної діяльності студентів. Адже мотивація впливає на студента, на його особистість загалом, на його емоційний стан, на його світогляд та уявлення про навколишній та внутрішній світ, сприйняття всього, що оточує його. Студент навчається не тільки задля того, щоб отримати нові знання, пізнати щось нове чи щось інше. Основною мотивацією студента стає професійне зростання, яке він отримає в результаті навчання, а також те, яке матеріальне забезпечення принесе ця робота йому в майбутньому. Також, безперечно, рівень мотивації студентів прямим чином впливає на їхню активність у процесі навчання. Адже кому буде потрібно витрачати свої сили та час на справу, яка є зовсім нецікавою. Тобто можна сказати, що мотиви - це основна рушійна сила студента до оволодіння новими знаннями [5].

Дистанційне навчання і мотивація студентів в цей період - це справжня больова точка сучасного суспільства. Студенти та викладачі зараз лише намагаються пристосуватися до нової форми навчання, вони стикаються з безліччю проблем на цьому шляху, по дорозі втрачаючи всю мотивацію, яка в них була. Саме тому дуже важливо вивчати цей аспект й за можливості допомагати та мотивувати студентів у цей складний період.

Мотивація студентів до навчання залежить від безлічі факторів, зокрема, віку студента та його вікових особливостей, характеру, темпераменту, рівня його професійної підготовки, інтересів, здібностей, талантів, його потенціалу студента, прагнення досягати вершин, 
стати справжнім майстром своєї справи, ставлення перед собою великих цілей. Не менш важливими фактором є сам ВНЗ та ті умови навчання, які він надає, заохочення, які використовує, а також перспективи, які наявні після закінчення цього навчального закладу [3].

Мотивація студентів в умовах дистанційного навчання цілковито відрізняється від звичної нам форми навчання. Адже відсутність потреби ходити до навчального закладу багато хто з них сприймає як позачергові канікули. Необхідно враховувати цей фактор, адже відсутність живого спілкування між викладачем і студентами, брак емоційного забарвлення, яке створює викладач під час очного процесу навчання, все це знижує мотивацію студентів до навчання.

Метою статті було дослідження мотивації навчання студентів в умовах дистанційного навчання.

Дослідження мотивації навчання студентів в умовах дистанційного навчання проводилося серед студентів 3 та 4 курсу спеціальності «Психологія» ПНПУ ім. Ушинського.

Діагностика проводилася в умовах дистанційного навчання за допомогою ресурсів Інтернету.

Всього у дослідженні брали участь 100 студентів віком від 19 до 24 років. 3 них 6 хлопців, 94 дівчат.

Дослідження проводилось за допомогою застосування методик: «Методика для діагностики навчальної мотивації студентів (А.А. Реана і В.А. Якуніна, модифікація Н.Ц. Бадмаєвой)» (табл. 1), «Мотивація навчання у вузі» (Т.Н. Ільїної) (табл. 2), «Мотиви вибору професії» (Р.В. Овчарова) (табл. 3) та розробленої нами анкети (табл. 4).

Як ми бачимо з таблиці 1, більшість досліджуваних мають комунікативні мотиви до навчання 50\%, мотиви творчої самореалізації мають 25\%, професійні мотиви - 10\%, соціальні мотиви $10 \%$, учбово-пізнавальні мотиви - 5\%, а мотиви уникнення і мотиви престижу - 0\%.

Як ми бачимо з таблиці 2, для більшості досліджуваних основною мотивацією до навчання є мотивація опанування професією $70 \%$, мотив до придбання знань - 25\% та мотив до отримання диплома - 5\%.

Як ми бачимо з таблиці 3, для більшості досліджуваних основним типом мотивації до обрання професії були внутрішні індивідуально значущі мотиви - 70\%, на другому місці зовнішні позитивні мотиви - 20\%, на третьому місці внутрішні соціально значущі мотиви 10\%, та зовнішніх негативних мотивів не простежується - 0\%.

Як ми бачимо з таблиці 4, більшість досліджуваних проявляють низький тип мотивації до навчання під час дистанційного навчання - 60\%, середній тип - 30\% та високий тип лише $10 \%$.
Таблиця 1

Результати дослідження за «Методикою для діагностики навчальної мотивації студентів" (А.А. Реана і В.А. Якуніна, модифікація Н.Ц. Бадмаєвой)

\begin{tabular}{|c|l|c|c|}
\hline № & Мотиви навчання студентів & $\begin{array}{c}\text { К-ть } \\
\text { сту- } \\
\text { ден- } \\
\text { тів }\end{array}$ & \% \\
\hline 1 & Комунікативні мотиви & 50 & $50 \%$ \\
\hline 2 & Мотиви уникнення & 0 & $0 \%$ \\
\hline 3 & Мотиви престижу & 0 & $0 \%$ \\
\hline 4 & Професійні мотиви & 10 & $10 \%$ \\
\hline 5 & Мотиви творчої самореалізації & 24 & $25 \%$ \\
\hline 6 & Учбово-пізнавальні мотиви & 6 & $5 \%$ \\
\hline 7 & Соціальні мотиви & 10 & $10 \%$ \\
\hline
\end{tabular}

Таблиця 2

Результати дослідження за методикою «Мотивація навчання у вузі» (Т.Н. Ільїної)

\begin{tabular}{|c|l|c|c|}
\hline № & Мотиви навчання студентів & $\begin{array}{c}\text { К-ть } \\
\text { сту- } \\
\text { ден- } \\
\text { тів }\end{array}$ & $\%$ \\
\hline 1 & Шкала «придбання знань» & 24 & $25 \%$ \\
\hline 2 & $\begin{array}{l}\text { Шкала «опанування профе- } \\
\text { сією» }\end{array}$ & 70 & $70 \%$ \\
\hline 3 & Шкала «отримання диплома» & 6 & $5 \%$ \\
\hline
\end{tabular}

Таблиця 3

Показники типів мотивації студентів під час вибору професії за методикою «Мотиви вибору професії (Р.В. Овчарової)

\begin{tabular}{|c|l|c|c|}
\hline № & \multicolumn{1}{|c|}{ Типи мотивації } & $\begin{array}{c}\text { К-ть } \\
\text { сту- } \\
\text { ден- } \\
\text { тів }\end{array}$ & $\%$ \\
\hline 1 & $\begin{array}{l}\text { Внутрішні індивідуально зна- } \\
\text { чущі мотиви }\end{array}$ & 70 & $70 \%$ \\
\hline 2 & $\begin{array}{l}\text { Внутрішні соціально значущі } \\
\text { мотиви }\end{array}$ & 10 & $10 \%$ \\
\hline 3 & Зовнішні позитивні мотиви & 20 & $20 \%$ \\
\hline 4 & Зовнішні негативні мотиви & 0 & $0 \%$ \\
\hline
\end{tabular}

Таблиця 4

Визначення типу мотивації до навчання досліджуваної групи під час дистанційного навчання за допомогою розробленої нами анкети

\begin{tabular}{|c|l|c|c|}
\hline № & \multicolumn{1}{|c|}{ Типи мотивації } & $\begin{array}{c}\text { К-ть } \\
\text { сту- } \\
\text { ден- } \\
\text { тів }\end{array}$ & \% \\
\hline 1 & Високий & 10 & $10 \%$ \\
\hline 2 & Середній & 30 & $30 \%$ \\
\hline 3 & Низький & 60 & $60 \%$ \\
\hline
\end{tabular}


Ці результати можна представити у вигляді діаграми (рис. 1).

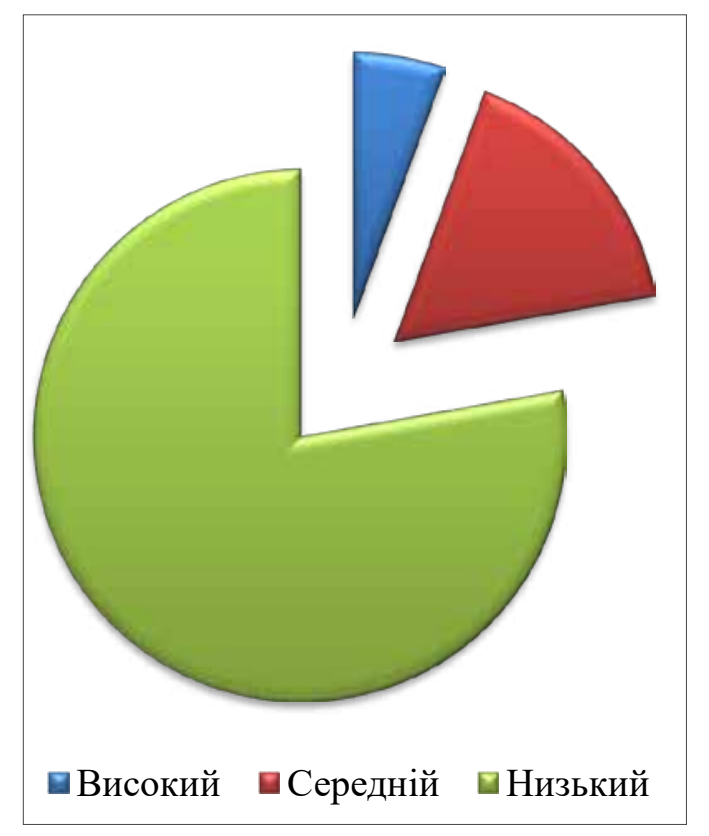

Рис. 1.

у результаті дослідження ми виявили, що більшість студентів мають комунікативні мотиви у навчанні, що свідчить про те, що одним із найважливіших факторів навчання для них є спілкування та взаємодія з оточенням. Також ми можемо підкреслити, що дуже важливим для досліджуваної групи студентів $€$ якісне опанування своєї професії, щоб стати справжнім фахівцем, майстром своєї справи. Важливо підкреслити, що основним рушієм під час вибору професії студентів стали індивідуально значущі мотиви. Це свідчить про те, що для них важливо, щоб обрана професія приносила задоволення, можна було б реалізувати свій творчий характер, спілкуватися з людьми.

Майже для всіх студентів дистанційне навчання $€$ першим досвідом, тому їм складно налаштуватися на такий режим, складно засвоювати більшість інформації шляхом самостійного навчання, складно сприймати матеріал через онлайн-конференції, складно взаємодіяти таким чином із викладачем та одногрупниками. А мотивація до навчання страждає у цей період не менше.

Низька мотивація до навчання студентів це справжня больова точка. Підсилити мотивацію студентів може батьківський контроль, їх співчуття та допомога в навчанні, допомога правильно розподілити навантаження, контроль відпочинку та багато іншого. Так, батьки можуть істотно вплинути на мотивацію студентів, але не всі батьки через ті чи інші обставини можуть проконтролювати «карантинне» навчання своїх дітей. Також слід зазначити, що багато студентів приїжджають з інших куточків держави чи світу і живуть самостійно чи у гуртожитках. Тут вплив батьків мінімізується, і необхідні інші осередки мотивації.

Питання мотивації студентів до опанування новими знаннями залишається досить складним. Найбільшим мотиватором до навчання все ж таки залишається мотивація оцінками. Адже студентам і так складно навчатися у новому форматі, деяким навіть на відстані від своїх родичів, а погані оцінки на додаток просто руйнують їх мотивацію вщент. Так, звичайно, набагато складніше зі студентами, для яких оцінки не мали значення і до карантину.

Однак аналіз певної літератури показав, що відвідування занять в онлайн-режимі майже не відрізняється від звичного нам режиму. А іноді ці показники навіть вище. В цей складний час люди почали цінувати спілкування з іншими, саме тому онлайн-заняття можуть стати мотиватором для студента. Адже він нарешті побачить та почує своїх одногрупників, з якими так довго не контактував. Потрібно давати можливість студентам під час конференцій взаємодіяти один з одним, спілкуватися, ділитися своєю думкою, посперечатися. Це буде цікавим для студента, його мотивація приходити на онлайн-заняття підвищиться.

Значна кількість студентів зазначає, що їхнє навантаження під час дистанційної форми навчання зросло. Викладачам необхідно навчитися розподіляти навантаження на студентів, намагатись допомагати їм 3 виникненням питань, навчитися бути терплячими, адже і тим, і тим зараз нелегко опанувати нову форму навчання.

Також аналіз літератури показав, що найбільшою проблемою студентів під час «карантинного» навчання стала відсутність зворотного зв'язку від викладачів щодо написаних робіт. Студенти намагаються виконувати вчасно всі завдання, а чи правильно вони були виконані, чи неправильно, чи можливо треба щось виправити - на ці питання їм ніхто не відповідає. Вони не розуміють, чи в правильному напрямку вони рухаються, чи правильно вони зрозуміли завдання, чи відповідає якість роботи очікуваній оцінці та чи можна взагалі виправити всі недоліки. Все це, безперечно, демотивує їх у виконанні поставлених завдань, виникає відчуття, що все робиться «в порожнечу». Адже студент декілька днів або навіть ночей може працювати над завданням, а в результаті не отримує жодного зворотного зв'язку від викладача. Лише у кінці семестру виявляється, що все було неправильно, а що саме - невідомо. Викладачі повинні розуміти, що студентам важливо дізнатися результат своїх старань, і тоді мотивація студентів значно підвищиться. 
Висновки 3 проведеного дослідження. Мотивація - це готовність людини докладати максимум зусиль задля досягнення своєї мети, якщо ця мета задовольняє якусь певну потребу цієї людини. Мотивація студентів до навчання залежить від безлічі факторів, зокрема, віку студента та його вікових особливостей, характеру, темпераменту, рівня його професійної підготовки, інтересів, здібностей, талантів, його потенціалу студента, прагнення досягати вершин, стати справжнім майстром своєї справи, ставлення перед собою великих цілей.

Мотивація студентів в умовах дистанційного навчання цілковито відрізняється від звичної нам форми навчання. Адже відсутність потреби ходити до навчального закладу багато хто сприймає як позачергові канікули.

Отже, діагностика та аналіз результатів показав, що більшість студентів проявляють низький тип мотивації під час дистанційного навчання. Це не є дивним, адже для них важливо спілкуватись, взаємодіяти з викладачами, одногрупниками, й тільки тоді навчання буде приносити задоволення, і буде мотивація опанувати свою професію. А під час карантину і дистанційного навчання ці можливості обмежені, тому про високу мотивацію до навчання в цей період не може бути й мови.

Мотивацію студентів можна підвищити шляхом втілення в навчальний процес методу тренінгу ті ігрового навчання, використання прикладів з життя, нового актуального матеріалу, найсучасніших методів викладання, комп'ютерних технологій. Також дуже важливим $€$ комунікативний зв'язок студента з викладачем та позитивна та емоційна атмосфера в аудиторії, можливість студента для мірку- вань, творчого мислення, самостійної роботи та самоконтролю.

Під час карантину найефективнішими способами вмотивувати студентів Є мотивація оцінками, можливість спілкуватися з одногрупниками, а також зворотний зв'язок від викладачів.

Результати нашого дослідження є дуже важливими і їх можна застосовувати практично. Адже саме завдяки дослідженню ми виявили, що все ж таки заважає мотивації студентів під час дистанційного навчання, і тому можемо розробити дієві корекційні програми задля їі підвищення.

\section{ЛITEPATУРA:}

1. Асеев В.Г. Мотивация учебной деятельности и формирование личности. Москва, 1976. 143 с.

2. Алексеева М.И. Мотивация учения студентов и удовлетворенность выбором вузом. Москва, 1986г. $135 \mathrm{C}$

3. Васильєва О.Г., Методика і техніка конкретного соціологічного дослідження. Київ, 2000. 64 с.

4. Грабал В. Некоторые проблемы мотивации учебной деятельности учащихся. Вопросы психологи. 1987. № 1. С. 5-6.

5. Гриншпун С.С. Интересы и склонности при выборе профессии. Школа и производство. 1985. № 6. С. 12-14.

6. Занюк С.С. Особливості та ефрективність фрормування мотивації учіння у студентів. Філософрія, соціологія, психологія: матеріали міжн. наук. конф. «Особистість в розбудові відкритого демократичного суспільства в Україні» (Івано-Франківськ, 6-7 жовтня 2000 р.). Івано-Франківськ, 2000. С. 74-79.

7. Кубышкина М.Л. Психологические особенности мотивации социального успеха : авторефр. дис. ... канд. псих. Наук : 19.00.05. Санкт-Петербург, 1997. $222 \mathrm{c}$

8. Яруліна Л.Р. Розвиток навчальної мотивації студентів. Социс. 2007. № 4. С. 30-32. 